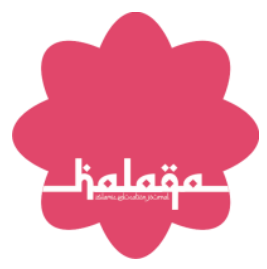

\title{
The chancellor's Leadership Style in Improver Lecturer Performance at the University of Muhammadiyah Jember
}

\section{Gaya Kepemimpinan Rektor Dalam Meningkatkan Kinerja Dosen Di Universitas Muhammadiyah Jember}

\author{
Saipul Wakit ${ }^{1 *}$, Ilfi Nurdiana ${ }^{2}$, Indah Yuliana ${ }^{3}$ \\ ${ }^{1}$ University of Muhammadiyah Jember, Indonesia, ${ }^{2,3}$ Maulana Malik Ibrahim State Islamic University Malang, \\ Indonesia
}

One indicator of a good university can be seen from the performance of lecturers who have been produced in a certain time. As for the performance of lecturers, it is specifically stated in the Tridharma of Higher Education which is an important element that must be implemented. In connection with this, improving performance requires the role of the leader, namely the Chancellor to provide direction, motivation, support and evaluation. With regard to these assumptions, it can be formulated that the purpose of this research has a concrete goal, namely to analyze and describe how the leadership style of the Chancellor of UM Jember in motivating, trying, and evaluating lecturer performance. The research method uses a qualitative approach with a case study design at UM Jember with data collection techniques through interviews, observation and documentation. The results of the study explain that the leadership style of the Chancellor of UM Jember in providing motivation to improve lecturer performance is carried out in a bureaucratic manner. The method used is direct motivation with spoken language on meeting agendas, university events, socialization, individual and general coordination with direct (instructive) and implied meanings (not instructive). In connection with the efforts that have been made by the Chancellor in improving the performance of lecturers through several work programs that have been mandated to structural leaders in charge of these tasks by involving the leaders of each unit under their auspices Practically the efforts that have been made by the Chancellor are related to the performance of lecturers related to the chess dharma of higher education, namely research, teaching, community service and Al-Islam kemuhammadiyahan. Meanwhile, the performance evaluation process for lecturers is carried out in coordination with leaders who have direct or indirect responsibilities and functions using performance appraisal instruments. 
Salah satu indikator perguruan tinggi yang baik dapat dilihat dari kinerja dosen yang telah dihasilkan dalam waktu tertentu. adapun kinerja dosen secara spesifik tertuang dalam tridharma perguruan tinggi yang merupakan unsur penting yang harus dilaksnakan. sehubungan dengan hal tersebut dalam peningkatan kinerja membutuhkan peran dari pemimpin yakni rektor untuk memberikan pengarahan, motivasi, dukungan dan evaluasi. Berkenaan dengan asumsi tersebut maka dari penelitian ini memiliki tujuan yang konkrit yakni untuk menganalisis dan mendeskripsikan bagaimanakah gaya kepemimpinan rektor UM Jember dalam memotivasi, upaya, dan mengevaluasi kinerja dosen. Adapun metode penelitian ini menggunakan pendekatan kualitatif dengan desain studi kasus di UM Jember dengan teknik pengumpulan data melalui wawancara, observasi dan dokumentasi. Adapun hasil penelitian menjelaskan bahwa gaya kepemimpinan rektor UM Jember dalam memberikan motivasi terhadap peningkatan kinerja dosen dilakukan secara birokratis. Adapun cara yang digunakan yaitu memotivasi langsung dengan Bahasa lisan pada agenda rapat, acara universitas, sosialisasi, kordinasi secara individu maupun general dengan ungkapan secara langsung (instruktif) maupun dengan makna tersirat (tidak bersifat instruktif). Berkaitan dengan upaya yang telah dilakukan rektor dalam meningkatkan kinerja dosen melalui beberapa program kerja yang telah diamanatkan kepada para pimpinan setruktural yang membawahi tugas tersebut dengan melibatkan pimpinan unit masing- masing di bawah naunganya. Secara praktis upaya yang telah dilakukan rektor terkait dengan kinerja dosen yang berhubungan dengan catur dharma perguruan tinggi yakni riset, pengajaran, pengabdian masyarakat dan Al- islam kemuhammadiyahan. Sedangkan proses evaluasi kinerja terhadap dosen dilakukan secara kordinatif dengan para pimpinan yang memiliki tanggung jawab dan fungsi secara langsung maupun tidak langsung dengan menggunakan instrument penilaian kinerja.

Kata Kunci: Gaya Kepemimpinan, Rektor, Kinerja dan Dosen 


\section{PENDAHULUAN}

Pada abad ke 21 ini pendidikan nasional sedang mengalami berbagai perubahan yang cukup mendasar dengan tujuan untuk memecahkan berbagai permasalahan pendidikan yang dihadapi saat ini. Pendidikan yang mengalami problematika tersebut diasumsikan mulai dari pendidikan tingkat dasar hingga perguruan tinggi. Permasalahan dalam perguruan tinggi yang dihadapi sangat beraneka ragam mulai dari masalah yang bersifat konvensional maupun masalah inovasi dalam pendidikan tinggi. Adanya perubahan tersebut harapanya dapat menciptakan iklim Pendidikan tinggi yang kondusif, berkualitas dan adanya pemberdayaan human resource management yang berkelanjutan Muwahid (2012). Sehingga dalam perguruan tinggi dibutuhkanya sumber daya manusia yang unggul dan berkualitas.

Poltak (2019) Memaparkan Sumber Daya Manusia yang disebut human resources merupakan unsur yang sangat penting dalam keberlangsungan sebuah organisasi publik maupun dalam dunia bisnis Gerry (2000). Sumber daya manusia yang merupakan elemen utama dalam menjalankan kinerja maupun program untuk mencapai visi dan misi lembaga. Berkaitan dengan sumber daya manusia maka Poltak (2019) menjelaskan bahwa ada empat prinsip dasar human resources yaitu: 1) sumber daya manusia merupakan capital (modal), 2) kebijakan organisasi sangat berhubungan dengan SDM, 3) budaya dan nilai- nilai organisasi dapat memberikan pengaruh terhadap kinerja SDM, dan 4) manajemen SDM bersifat integrated terhadap seluruh lini organisasi dalam mencapai tujuan.

Dalam konteks perguruan tinggi kepemimpinan merupakan unsur yang sangat setrategis, karena kepemimpinan memiliki peran untuk mendorong perubahan dalam sebuah organisasi. Kepemimpinan dalam organisasi Pendidikan tinggi tentunya Rektor memimpin pada tingkat universitas, dekan dalam lingkup fakultas dan kaprodi pada tingkat program studi secara nyata merupakan pemimpin yang berperan dalam menentukan kinerja organisasi perguruan tinggi Poltak (2019). Rektor sebagai pimpinan tertinggi dalam lembaga pendidikan tinggi merupakan salah satu unsur yang berperan penting untuk menggerakan kinerja sumber daya manusia yang ada. Menurut Peraturan Pemerintah Republik Indonesia bagian Ke enam tentang Undang- Undang Peguruan Tinggi Nomor 69 Tahun 2012 bahwa yang tergolong Sumber Daya Manusia perguruan tinggi adalah dosen dan tenaga kependidikan. Menurut Suharsaputra (2015) Kedua Jenis sumber daya manusia perguruan tinggi tersebut merupakan komponen yang terintegrasi yang merupakan satu kesatuan team working dalam mewujudkan tujuan perguruan tinggi. Sehingga rektor perlu meningkatkan kinerjanya baik secara kualitatif maupun kuantitatif harapanya ketika kinerja baik maka dapat membantu rektor dalam menjalankan peranya untuk mewujudkan tujuan perguruan tinggi yang baik di masyarakat.

Perguruan tinggi sebagai Lembaga Pendidikan yang telah lama tumbuh dan berkembang tentunya menjadi sebuah lembaga yang bersifat kompleks dan unik. Perguruan tinggi bersifat kompleks karena memiliki fungsi ganda yang berbeda dengan lembaga pendidikan lainya. Hal tersebut sebagaimana dijelaskan dalam Undang- Undang Pendidikan Tinggi No. 12 Tahun 2012, Pasal 4 bahwa perguruan tinggi memiliki fungsi (1) pengembangan kemampuan dan pembentukan karakter dalam mencerdasakan kehidupan bangsa, (2) pengembangan iklim akademik dengan berinovasi, kreatif, terampil, kompetitif dan mampu berkerja sama melalui kegiatan tridarma perguruan tinggi, (3) pengembangan iptek dengan menerapkan nilai- nilai humaniora.

Konsekuensi dari pelaksanaan Pendidikan tinggi tersebut sangat dibutuhkanya peran yang aktif dari rektor selaku pimpinan perguruan tinggi melalui kemampuan manajerial yang baik serta dukungan kinerja dari tenaga kependidikan maupun dosen secara professional. Karena mengingat tanggung jawab yang paling besar terletak pada rektor sebagai seorang pemimpin dan peran kepemimpinanya. Menurut Muwahid Sulhan salah satu faktor yang mempengaruhi berhasil tidaknya sebuah tujuan lembaga pendidikan dipengaruhi oleh faktor kepemimpinan Sulhan (2012). Pernyataan tersebut dipertegas oleh Fred Hecniger bahwa kualitas sebuah Lembaga Pendidikan itu dapat mengalami peningkatan maupun penurunan dalam setiap kasus tentunya sangat dipengaruhi oleh kualitas pemimpinya.

Paparan di atas tentunya memberikan bukti bahwa kepemimpinan dapat menentukan efektifitas dalam kinerja dosen. Secara empiris Sunarsih (2015) menjelaskan dalam risetnya bahwa gaya kepemimpinan dalam mengimplementasikan fungsi dosen secara professional tentunya dapat tercipta iklim Pendidikan dan pembelajaran di lingkungan kampus secara efektif dan efisien. Iklim kampus yang kondusif tentunya terdapat hubungan harmonisisasi yang tinggi diseluruh warga kampus mulai dari stakeholder, dosen, karyawan maupun mahasiswa sehingga kondisi tersebut dapat berdampak pada kinerja yang tinggi. Iklim kondusif dapat memberikan gambaran bahwa di dalam perguruan tinggi memiliki komitmen terhadap peningkatan kegiatan tridharma perguruan tinggi secara sungguh-sungguh serta mengisyaratkan adanya kepedulian terhadap terpenuhinya kebutuhan dosen dan mahasiswa secara akademik.

Dari beberapa pandangan tersebut maka keberhasilan suatu perguruan tinggi sangat ditentukan oleh kecakapan dan gaya kepemimpinan rektor dalam mencapai tujuan yang ingin dicapainya. Rektor sebagai pemimpin diharapkan mampu untuk mempengaruhi, mengajak, mendorong, memerintah, membimbing, dan memaksa orang lain (dosen) untuk bekerja demi mencapai tujuan dan menciptakan suatu iklim yang kondusif demi tercapainya tujuan perguruan tinggi. Hasan (1991). Berdasarkan undang- undang No.12 Tahun 2012 tentang Pendidikan tinggi pasal 1 ayat 2 bahwa dosen sebagai pendidik di lingkungan Perguruan tinggi, memegang peranan penting dalam pendidikan, untuk penyiapan dan pembentukan sumber daya manusia Indonesia yang unggul, Syahrizal (2009). Menurut Suharsaputra (2015) dalam pengelolaan sebuah pendidikan perlu tersedianya human capital (dosen) yang memiliki kualitas agar menghasilkan output yang berkualitas pula. Penjelasan tersebut dipertegas oleh Ndraha human capital yang berkualitas baik adalah sumber daya manusia atau personality yang tidak hanya memiliki kemampuan kerja secara komparatif namun juga harus memiliki competitif value secara general, Sutrisno (2017). Sehingga dari uraian tersebut dapat dimaknai untuk 
menghasilkan lulusan berkualitas maka diperlukan dosen yang berkualitas dan memiliki prestasi kerja yang baik. Sedangkan prestasi kerja dosen yang baik perlu ditunjang oleh kepemimpinan rektor selaku manager di perguruan tinggi.

Salah satu faktor yang menjadi tolak ukur keberhasilan sebuah perguruan tinggi adalah kinerja dosen. Kinerja dosen yang dimaksud adalah hasil kerja guru/ dosen yang telah direfleksikan dalam perencanaan, pelaksanaan, dan penilaian kegiatan tridharma perguruan tinggi dengan dilandasi etos kerja yang baik, disiplin dan professional, Wahyumijo (2003). Secara rinci indikator kinerja dosen dijelaskan oleh Dirjen Dikti di dalam Pedoman Beban Kerja Dosen Dan Evaluasi Pelaksanaan Tridharma Perguruan Tinggi Tahun 2010, terdiri dari kinerja Pendidikan, penelitian, pengabdian masyarakat dan kinerja penunjang. Kinerja dosen secara umum menurut Mathis and Jacson (2008) dapat dilihat dari empat indikator yaitu 1) kualitas kerja yang dihasilkan, 2) efisiensi waktu yang digunakan, 3) kuantitas kerja, 4) kemampuan team working dengan sesama pegawai yang lebih luas. Menurut Yoyo (2018) kinerja memiliki sifat yang multidimensi yang dapat menghasilkan sesuatu secara fisik maupun non fisik serta materi maupun non materi. Secara eksplisit Hasibun memberikan pemahaman secara praktis bahawa kinerja itu merupakan hasil kerja yang telah dilaksanakan oleh seseorang dari tugas yang diberikan kepadanya.

Dalam konteks meningkatkan kinerja dosen di perguruan tinggi maka perlu dilakukan pengelolaan secara terencana, dan sitematis sehingga dalam kinerja organisasi dapat terlaksana dengan baik. Kinerja dosen merupakan hal yang sangat penting dalam mewujudkan Pendidikan yang berkualitas. Menurut Barney dosen memiliki peranan penting dalam menghadapi competitive advantage perguruan tinggi. Kinerja dosen yang berkualitas tentunya banyak dipengaruhi oleh beberapa faktor diantaranya adalah kepemimpinan yang dilakukan oleh atasan terhadap bawahan. Peran pemimpin sangat penting dalam sebuah organisasi karena jika tidak ada pemimpin dalam sebuah lembaga organisasi maka hanya menggambarkan kumpulan dari beberapa mesin dan kumpulan orang. Mengingat kepemimpinan adalah kemampuan dan kesiapan seseorang dalam mempengaruhi, mendorong, mengajak, memantau, serta memaksa sesorang untuk mengikuti pengaruhnya demi mencapai tujuan yang dicita- citakan, Dirawat (2015).

Penelitian ini menjadi penting karena mengingat prestasi kerja dosen yang tinggi dapat diwujudkan melalui kinerjanya, yang merupakan hasil aplikasi dari motivasi diri maupun dampak dari gaya kepemimpinan rektor selaku pimpinan. Dengan adanya prestasi kerja dosen yang tinggi menunjukan berjalanya dengan baik fungsi dosen sebagai pendidik dan terlaksananya tridharma perguruan tinggi dalam sebuah lembaga. Namun sebaliknya jika prestasi kerja dosen rendah maka menunjukan tidak efektifnya fungsi dosen dilembaga tersebut. Sebagaimana dijelaskan oleh Soewarto (2012) bahwa rendahnya kinerja dosen terjadi karena beberapa sebab yakni bukan karena kesalahan dari dosen itu sendiri namun ada penyebeb lain diantaranya 1) tiadak adanya perhatian dari para stakeholder (unsur pimpinan) kampus, 2) hubungan kerja yang tidak harmonis, 3) rendahnya kesejahtraan dosen, 4) rendahnya motivasi, dan 5) rendahnya kepuasan kerja yang dialami dosen.
Rendahnya kinerja dosen menurut hasil riset Yudita (2015) secara mendasar ditentukan oleh kompetensi seseorang dalam hal pengetahuan, keterampilan, kualitas, sumber daya dosen, kepribadian, motivasi dan budaya organisasi yang ada, Sudarso (2018). Namun menurut Soewarto (2012) dari hasil risetnya rendahnya kinerja dosen disebabkan oleh beberapa faktor yakni motivasi, kepemimpinan, kompensasi dan kepuasan kerja dosen. Pandangan lain berdasarkan hasil riset Nurul (2012) memberikan keterangan bahwa budaya organisasi dapat mempengaruhi kinerja dosen, karena semakin tinggi budaya organisasi maka berpengaruh terhadap peningkatkatan kinerja dosen. Begitu pula kompetensi sangat mempengaruhi kinerja dosen sebagaimana di jelaskan oleh Haris (2012) dalam risetnya bahwa semakin tinggi kompetensi yang dimiliki oleh dosen maka dapat meningkatkan kualitas dan kuantitas kinerjanya. Melihat kinerja dosen Brojonegoro (2008) menjelaskan beberapa indikator yaitu yang berkaitan dengan tridharma Pendidikan tinggi yakni a) berkualitas dan relevansinya lulusan b) berkualitasnya penelitian, dan c) berkualitasnya pengabdian masyarakat.

Berdasarkan paparan data di atas tentang rendahnya kinerja dosen menurut hasil riset Soewarto salah satunya dipengaruhi oleh faktor kepemimpinan. karena mengingat bahwa esensi dari kepempinan rektor adalah terletak pada peranya yaitu sebagai pejabat formal, manager, leadership, administrator, supervisor, motivator, innovator, dan penggerak. Sehingga dalam menjalankan peran kepemimpinan maka rektor harus memiliki sifat- sifat khusus kepemimpinan efektif. Menurut Yukl (2014) dalam Usman kepemimpinan efektif yang harus dimiliki rektor adalah percaya diri, kematangan emosional, mampu mengelola setres, memiliki motivasi yang tinggi dan memiliki integritas diri misalnya sifat jujur dan konsiten terhadap keputusan dan tujuan.

Paparan di atas mempertegas pentingnya kepemimpinan rektor dalam upaya peningkatan kinerja dosen. Menurut hasil riset Khairul (2019) kunci keberhasilan kinerja dosen harus didukung motivasi dalam diri dosen serta didukung oleh sistem dan kebijakan lembaga yang baik. Adapun faktor pendukung kinerja penelitian menurut Huda and Rohmah (2018) ada lima komponen yaitu 1) tersedianya pembiayaan penelitian, 2) ketersediaan dana untuk kegiatan pelatihan atau workshop, 3) adanya fasilitas publikasi yang ber ISBN, 4) adanya reward kepada dosen yang aktif publikasi ilmiah dan 5) dosen mengikuti kegiatan ilmiah baik forum nasional maupun internasional, Huda (2018) dalam Tri Hartiti. Universitas Muhamamdiyah Jember dipilih peneliti sebagai fokus lokasi penelitian karena peneliti mengamati adanya upaya- upaya rektor dalam meningkatkan kinerja dosen serta adanya capaian- capain yang telah dilakukan oleh rektor di UNMUH Jember.

\section{METODE}

Desain penelitian dalam artikel ini adalah kualitatif yang memiliki tujuan untuk mengungkap dan menggali secara mendalam terhadap fokus penelitian dalam penelitian ini. Selain itu juga peneliti akan mengungkap fenomena yang ada dilapangan guna menjawab fokus penelitian. Adapun Jenis penelitian yang peneliti gunakan dalam kajian ini adalah studi 
kasus, secara khusus mengungkap gaya kepemimpinan rektor dalam meningkatkan kinerja dosen di UM Jember. Adapun Teknik pengumpulan data dengan memanfaatkan data primer dan sekunder serta menggali informasi kepada informan. Selain itu juga peneliti melakukan pengamatan dan terjun langsung dalam menggali data di lapangan. Setelah data yang dibutuhkan terpenuhi maka dilakukan sebuah analisis data, selanjutnya dilakukan sebuah pengecekan keabsahan data melalui kredibiltas, tranferbilitas, dependibilitas dan confirmabilitas data.

\section{1) Pendekatan dan Jenis Penelitian}

Landasan dasar atau paradigma yang peneliti gunakan dalam penelitian ini adalah interpretif, Djunaidi and Fauzan (2017) Sedangkan untuk pendekatan penelitian ini adalah kualitatif, karena dalam penelitian ini peneliti mencari dan mendeskripsikan secara mendalam dan penafsiranya bersifat holistik John (2015) tentang gaya kepemimpinan rektor dalam meningkatkan kinerja dosen di perguruan tinggi swasta yakni di Universitas Muhammadiyah Jember. Namun disini proses yang peneliti maksud adalah motivasi. pengarahan, meggerakan dan mengevaluasi kinerja dosen tentunya peneliti angkat dan deskripsikan sesuai kondisi yang sebenarnya.

Jenis penelitian yang peneliti gunakan dalam kajian ini adalah studi kasus. Jenis ini peneliti pilih karena peneliti hendak terjun langsung ke lapangan guna untuk memperoleh data emik melalui observasi, dengan mengedepankan karakteristik lembaga yaitu yang berkedudukan sebagai lokus

2) Kehadiran Peneliti

Penelitian kualitatif mengharuskan kehadiran dan keterlibatan peneliti secara langsung dalam proses penelitian. Proses penelitian ini mencakup proses perencanaan penelitian, pelaksanaan perencanaan dan pelaporan penelitian. Sebagai instrumen kunci Sugiono (2015) pada proses perencanaan, peneliti melakukan rangkaian akademik yang memiliki keterkaitan dengan penelitian ini. Peneliti melakukan wawancara secara mendalam dengan menggunakan metode snow ball sampling Sugiono (2015) dengan berwawancara, menggali dan mengumpulkan data kepada pihak- pihak yang berkompeten dalam hal- hal yang dibutuhkan oleh peneliti

3) Data dan Sumber Data Penelitian

Data dalam penelitian adalah informasi dan fakta (Sugiono (2015) yang berhubungan dengan gaya kepemimpinan rektor yang berkaitan dengan memberi motivasi, mengarahkan, menggerakan dan mengevaluasi kinerja dosen. Data tersebut dapat diperoleh melalui aktivitas, lokasi, dokumen dan informasi dari para informan. Berkaitan dengan kategorisasinya, peneliti mengolongkan dua kategori data yaitu primer Sumardi (1998) dan sekunder Mudjia (2018) Data primer dalam penelitian ini dapat berupa kumpulan data, narasi, konteks, dan pernyataan yang disampaikan oleh informan dan tertulis berkaitan dengan motivasi, mengarhkan, menggerakan dan mengevaluasi kinerja dosen. Sedangkan untuk data sekunder yaitu data yang menjadi pendukung analisis, struktur organisasi, gaya kepemimpinan, kinerja dosen, data dosen serta dokumendokumen lainya. Kategori sumber data dalam penelitian ini dibedakan menjadi dua yaitu manusia dan bukan manusia. Human dalam kapasistasnya menjadi sumber data (key informan) Mudjia (2018) dalam seluruh rangkaian gaya kepemimpinan rektor. Dalam konteks ini pihak yang terlibat yaitu pada level pimpinan diperguruan tinggi, yang merupakan key informan pada penggalian gaya kepemimpinan rektor yang ada dilembaga tersebut. Sumber data yang lain yakni bukan manusia yang dapat diperoleh dari informasi data atau soft data, dokumen, aktifitas dan tempat penelitian Creswel (2015) Pada sumber ini peneliti akan menelusuri keberadaan data- data tersebut yang berkaitan dengan gaya kepemimpinan rektor dalam meningkatkan kinerja dosen di UM Jember.

\section{[Table 1 about here.]}

\section{4) Teknik Pengumpulan Data}

Teknik Pengumpulan Data yang peneliti gunakan dalam eksplorasi data yaitu teknik yang dikemukakan oleh Bogdan dan Biklen, yaitu: 1) wawancara mendalam (Indepth Interview), 2) Observasi Partisipan dan 3) studi dokumentasi (Study Document) Bogdan (1992). Teknik ini dipilih oleh peneliti karena peneliti diberikan ruang yang luas untuk menggali data secara holistik dan inten. Proses wawancara mendalam yang akan peneliti lakukan tidak dibatasi dengan frequensi tertentu. Karena peneliti lebih mendahulukan memperoleh data- data langsung yang bersifat mendalam. Pemilihan informan dalam melakukan wawancara, peneliti akan memilih informan yang memiliki kapasitas, pengetahuan secara spesifik, informatif yang dekat dengan situasi yang menjadi fokus penelitian. Disamping memiliki status tertentu keterlibatan informan dalam memahami gaya kepemimpinan rektor akan menjadi pertimbangan penting bagi pemilihan informasi yang akurat, khususnya menjadi key informan. Rancanagn wawancara yang hendak peneliti lakukan dalam penelitian ini akan dijelaskan ditabel di bawah ini:

[Table 2 about here.]

Dokumentasi pada bagian ini peneliti akan menelaah datadata dokumen yang dapat dijadikan data Primer maupun data Sekunder. Yang mana rancangan ini secara rinci akan diuraikan dalam tabel berikut ini:

\section{[Table 3 about here.]}

\section{5) Teknik Analisis Data}

Teknik analisis data dalam penelitian ini dilakukan dengan dua model yaitu, analisis kasus tunggal dan lintas situs. Masing- masing tahapan dari dua model tersebut akan diuraikan lebih lanjut:

[Figure 1 about here.]

6) Pengecekan Keabsahan Data

Validasi data yang peneliti gunakan dalam penelitian ini mencakup empat pada empat kriteria berikut ini: a) Derajat kepercayaan (credibitity), untuk memperoleh data yang benar dan dapat dipertanggung jawabkan, peneliti sering 
melakukan telaah dan membandingkan setiap data dari berbagai macam sumber, jenis dan tingkat kebaruan. Begitu pula dalam penyajian, peneliti banyak mendialogkan datadata yang didapatkan dengan berbagai macam sumber yang telah ditemui peneliti; b) Keteralihan (transferabitity), agar penelitian ini tidak sia-sia, dalam konteks ini peneliti akan senantiasa melakukan penghayatan, membuat abstraksi, agar konsep, temuan dan data yang dipaparkan dalam penelitian ini dapat diserap dan ditransfer kepada lokasi lain; c) Kebergantungan (dependability), intensitas pertemuan peneliti dengan para ahli menjadi wujud dari upaya untuk menguji keabsahan data dalam penelitian ini. Selain melakukan pengecekan lapangan, melakukan kajian lintas dokumen, peneliti selalu berdiskusi dengan para ilmuan yang memiliki kompetensi pada bidang ini; d) Kepastian (confirmability), unsur akademik yang menjadi jaminan bagi peneliti dan mengawal kualitas dan kevalidan hasil penelitian ini adalah dengan diskusi kepada para pakar walaupun tanggung jawab akademik lebih besar pada peneliti.

7) Tahapan Penelitian

Tahapan penelitian yang telah peneliti lakukan adalah sebagai berikut: a) Tahap Melakukan Kajian Pendahuluan. Sebuah kegiatan dalam penelitian ini mengkaji beberapa referensi maupun hasil riset terdahulu dalam bentuk jurnal nasional maupun internasional tentang gaya kepemimpinan. Dalam kajian terdahulu ini peneliti melihat relevansi dan manfaat dari kepemimpinan bagi dosen atau karyawan; b) Tahap merancang Desain Penelitian. Setelah melakukan observasi awal maka peneliti menetapkan permasalahan yang akan diteliti pada lokasi penelitian. Sedangkan kegiatan berikutnya adalah membuat desain penelitian; c) Tahap Penelitia. Tahapan penelitian yang paling awal adalah menyampaikan surat izin penelitian kepada Rektor UM Jember, Setelah itu baru peneliti mulai melakukan observasi awal, wawancara pendahuluan, pengumpulan data, mengelompokan data, pengolahan data, konfirmabilitas data, analisis data dan penulisan hasil penelitian. Setealah tahapan tersebut selesai maka dilanjutkan dengan menganalisis data; d) Tahap Penulisan Laporan. Tahapan terakhir yaitu menulis laporan penelitian, dengan menganalisis data yang ada kemudian dituangkan dalam sebuah karya ilmiah. Adapun susunan penulisan laporan penelitian berdasarkan panduan penulisan karya ilmiah; e) Tahapan Publikasi. Publikasi dilakukan sesuai luaran wajib yakni terbit di jurnal nasional terakreditasi dengan menyusun artikel dan kemudian mengirim kepada jurnal yang dituju.

\section{HASIL DAN PEMBAHASAN}

\section{Gaya Kepemimpinan Rektor UM Jember Dalam Memotivasi Dosen Untuk Meningkatkan Kinerja}

Motivasi merupakan unsur penting yang ada dalam diri setiap individu yang dimiliki oleh setiap orang. Menurut $G$ Terry motivasi merupakan sebuah keinginan dalam diri seseorang untuk melakukan tindakan. The Liang Gie memaparkan lebih lanjut bahwa motivasi adalah sebuah pekerjaan yang dilakukan oleh seseorang dalam memberikan inspirasi, semangat, dorongan dalam mengambil tindakan. Sedangakan Edwin E Chisseli dan Clarece W Brown, motivasi merupakan sebuah proses untuk menumbuhkan sebuah keinginan dan kebutuhan dalam motif tertentu. Dalam pandangan lain George Stranus dan Leonard Slas menjelaskan bahwa motivasi merupakan seseorang dapat menciptakan sesuatu situasi yang karyawan dapat puas melaksanakan tugas yang berorientasi pada organisasi. Sondang Siagian memperjelas bahwa proses motivasi dilaksanakan secara sedemikian rupa sehingga pegawai ihlas melaksanakan tugasnya, Sondang (2016).

Teori tersebut bila dikaitkan dengan gaya kepemimpinan maka sangat relevan karena dalam kepemimpinan seorang pemimpin senantiasa memberikan motivasi kepada para bawahanya. Bila melihat kasus yang ada di UM Jember maka rektor selaku pimpinan tertinggi dalam lembaga perguruan tinggi maka memiliki peran untuk menggerakan maupun memberikan motivasi kepada para bawahanya yakni para karyawan dan dosen untuk senantiasa meningkatkan kinerjanya. Dalam memberikan motivasi kepada para karyawan khususnya dosen dengan beberapa macam cara atau style. Adapun cara memberikan motivasi dilakukan dengan dua acara yakni 1) dilakukan secara langsung melalui lisan dalam sebuah pertemuan secara pribadi, acara universitas, rapat maupun sosialisasi. 2) dilakukan secara lisan namun dengan makna tersirat yakni memberikan uraian atau penjelasan tentang hal- hal yang harus dicapai UM Jember dimasa yang akan datang dengan sebuah harapan dan contoh. Adapun motivasi yang diberikan berupa motivasi tentang kinerja yang sesuai dengan tugas pokok masingmasing. paparan tersebut sebagaimana dijelaskan dalam wawancara dengan sekretaris LPAIK UM Jember berikut ini ini: Menurut pengamatan saya pak rektor selalu memberikan motivasi kepada para dosen untuk meningkatkan kinerjanya yang berkaitan dengan catur dharma yakni dharma pengajaran, penelitian, pengabdian masyarakat dan alIslam kemuhammadiyahan. Saya sering mengikuti acara di universitas ketika pak rektor memberikan sambutan maka selalu memberikan motivasi kepada kita semua untuk memajukan UM Jember secara bersama- sama. Adapun bentuk motivasi kadangkala secara langsung maupun dengan makna tersirat (Wawancara Sekretaris LPAIK/ 19/4/2021)

Berkaitan dengan motivasi dalam meningkatkan kinerja dosen maka rektor UM Jember lebih menekankan pada peningkatan kinerja yang berkaitan dengan kewajiban dosen yakni melaksanakan tridharma perguruan tinggi maupun catur dharma yakni ada muatan Al- Islam dan kemuhammadiyahan. Dimana para dosen dianjurkan untuk senantiasa aktif melakukan penelitian dan pengabdian masyarakat dengan didukung publikasi ilmiah baik nasional maupun internasional.

Uraian di atas tentunya dapat dimaknai bahwa dalam kinerja dosen rektor UM Jember mengharapkan adanya keseimbangan dalam melaksanakan tridharma atau catur dharma. Dimana rektor menghendaki dosen tidak hanya mengajar mahasiswa dalam kelas namun dharma yang lain harus dilaksanakan dengan baik berupa penelitian, pengabdian dan publikasi ilmiah. Hal ini dilakukan karena kegiatan meneliti atau mengabdi itu merupakan kegiatan yang 
membutuhkan motivasi dan keterampilan setiap dosen. Sehingga para dosen harus sering diingatkan dan dimotivasi akan kewajibanya serta tanggung jawabnya tidak terlupakan. Selain itu juga dosen harus dapat melaksnakan dan menerapkan nilai- nilai Al- islam dan kemuhammadiyahan di lingkungan masyarakat masing- masing dengan aktif mengikuti pengajian ranting maupun kajian- kajian Muhamamdiyah lainya. Produktifitas dapat dipengaruhi oleh beberapa faktor penting yaitu pengetahuan, kemampuan, sikap dan tingkah laku. Dari komponen teori tersebut maka kerangka berfikir dalam konteks kelembagaan perguruan tinggi dapat digambarkan sebuah bagan yang saling berkorelasi antara faktor yang satu dengan faktor yang lain. Lebih jelasnya dapat dilihat di bawah ini:

\section{[Figure 2 about here.]}

Berdasarkan fenomena dan teori yang dikemukakan oleh Klinger maka motivasi yang dilakukan oleh rektor UM Jember memiliki tujuan yakni untuk memberikan penghargaan maupun untuk meningkatkan produktifitas kerja para dosen. Namun dalam konteks peningkatan kinerja disebuah perguruan tinggi maka motivasi yang diberikan oleh pimpinan kepada bawahan lebih cenderung pada dua hal yakni pemberian penghargaan dan peningkatan produktifitas kerja. Hal ini terjadi karena intitusi perguruan tinggi berbeda dengan intitusi yang bergerak dalam dunia usaha atau profit. Dari sini secara paradigma dan tujuan dalam memberikan motivasi tentunya sangat berbeda walaupun ada kalanya ada sisi kesamaanya. Jika digambarkan dalam sebuah bagan maka model motivasi yang diberikan rektor dalam rangka meningkatkan kinerja maka lebih cenderung bersifat top down dan hubungan vertikal dari atas ke bawah yang menunjukan fungsi leadership seeorang rektor.

\section{[Figure 3 about here.]}

\section{Upaya Rektor UM Jember Dalam Meningkatkan Kinerja Dosen}

Upaya rektor dalam meningkatkan kinerja dosen tentunya dilakukan berdasarkan asas kebutuhan dan situasi. Selain itu juga upaya rektor dalam peningkatan kinerja dosen dalam hal catur dharma sebagai indikator kinerja yang baku dan berdasarkan keputusan kementrian pendidikan dan kebudayaan direktorat perguruan tinggi. Merujuk upaya rektor dapat dimaknai sebuah usaha yang dilakukan rektor berserta jajarannya dalam meningkatkan kinerja dosen secara umum. Adapun mekanismenya tentunya rektor melakukan kordinasi dan menampung aspirasi dari para dosen melalui pimpinan unit maupun senat terkait dengan permasalahan yang dihadapi oleh para dosen terkait dengan peningkatan kinerja. Dari paparan tersebut maka dapat diambil sebuah pengertian bahwa upaya rektor dalam peningkatan kinerja dosen dilakukan secara birokratis melalui wakil rektor dan pimpinan unit di bawahnya. Dari setiap unit di bawahnya memiliki peran dan tanggung jawab masing- masing guna mewujudkan visi dan misi rektor. Selain itu juga upaya rektor dalam menopang kinerja dosen antara lain sebagaimana dijelaskan oleh dekan fakultas ilmu kesehatan sebagai berikut:

Dari uraian di atas secara spesifik dalam hal pengajaran dan pembelajaran upaya- upaya yang dilakukan rektor dalam peningkatan kinerja dosen meliputi beberapa hal dan strategis yaitu: 1) Sosialisasi kurikulum merdeka belajar kampus merdeka; 2) Pelatihan penyusunan kurikulum terbaru terkait dengan MBKM; 3) Sosialisasi pedoman Rencana Pembelajaran Semester; 4) Workshop penyususnan Rencana Pembelajaran Semester; 5) Mengadakan pelatihan Pekerti dan Aplied Aproach; 6) Melakukan renovasi terhadap kelas yang representative dan nyaman untuk belajar; 7) Memaksimalkan pemanfaatan sarana dan prasarana yang ada di lingkungan universitas Muhamamdiyah Jember; 8) Meningkatkan kesejahtraan dosen dan karyawan melalui tambahan gaji pokok.

Berkaitan dengan kinerja dharma penelitian dan pengabdian masyarakat upaya rektor melalui unit LPPM di bawah naungan Wakil Rektor I. Selain itu juga berkaitan dengan peningkatan peningkatan riset dan pengabdian masyarakat maka rektor telah memberikan subsidi kepada dosen yang mempublikasikan karyanya kejurnal nasional sinta 1 dan 2 serta publikasi ke jurnal internasional terindex. Dari uraian di atas maka dapat diambil sebuah benang merah bahwa apaya yang teah dilakukan oleh rektor dalam peningkatan kinerja dosen bidang riset, pengabdian masyarakat maupun publikasi dapat disimak berikut ini: 1) Memberikan bantuan pendanaan riset dan pengabdian masyarakat kepada dosen UM jember; 2) Menambah jumlah pendanaan dan kuota riset bagi dosen melalui beberapa klaster penelitian; 3) Rektor telah berpartisipasi dalam kegiatan anggunan pendanaan riset bagi dosen PTMA yang dikelola oleh Diktilitbang PP Muhamamdiyah; 4) Memberikan pendanaan bagi dosen dalam kegiatan publikasi ilmiah untuk jurnal terindex sinta 1 dan 2 maupun jurnal internasional terindex scopus; 5) Melakukan kegiatan worksop dan klinik penulisan proposal riset dan pengabdian masyarakat bagi dosen; 6) Melakukan kegiatan klinik artikel untuk publikasi ilmiah jurnal nasional maupun internasional terindex.

Selanjutnya berkaitan dengan peningkatan dharma alislam dan kemuhamamdiyahan bahwa dalam peningkatan kinerja dosen dalam bidang al- islam dan kemuhammadiyahan melalui LPAIK di bawah naungan Wakil Rektor I dilakukan beberapa hal berikut ini: 1) Telah dilaksanakanya kegiatan Baitul arqom bagi dosen dan karyawan; 2) Pelatihan instruktur bagi dosen dilingkungan UM Jember; 3) Disarankan bagi para dosen dan karyawan untuk aktif mengikuti kegiatan pengajian setiap ahad pagi; 4) Kegiatan seminar maupun bedah buku tentang idiologi Muhammadiyah bagi dosen UM Jember.

Berdasarkan uraian di atas upaya rektor dalam meningkatkan kinerja dosen dilakukan secara prosedural dan birokratif. Karena rektor sebagai pimpinan tertinggi dalam sebuah perguruan tinggi maka memiliki bawahan yang membantu dalam menyelesaikan tugas dan tanggung jawabnya maupun untuk mewujudkan visi dan misi lembaga organsisasi. Dengan demikian maka alur kerja yang dilakukan rektor bersifat setruktural dengan memperdayakan sumber daya yang ada baik ditingkat rektorat maupun tingkat unit. Adapun kinerja dosen yang bersifat catur dharma maka dapat digambarkan sebagai berikut ini: 
[Figure 4 about here.]

Dari gambar tersebut dijelaskan bahwa fungsi rektor sebagai pimpinan yang mengakomodir dan membawahi dari para pimpinan di bawahnya yang bersifat setruktural. Secara kordinatif maka penanggung jawab masing- masing dharma yang merupakan kinerja dosen di bawah kewenangan Wakil Rektor I namun pertanggungjawabanya kepada rektor selaku pimpinan lembaga atau organisasi.

\section{Gaya Kepemimpinan Rektor UM Jember Dalam Mengevaluasi Kinerja Dosen}

Dalam ruang lingkup manajemen sumber daya manusia penilaian atau evaluasi merupakan unsur yang sangat penting. Untuk melihat sejauh mana tujuan organisasi tercapai dengan baik atau tidak maka dapat dilihat dari hasil evaluasi yang telah dilakukan. Secara umum menurut Sondang Siagian memiliki tujuan untuk menilai pegawai secara personal dan menilai untuk organisasi atau lembaga. penilaian bagi pegawai tentunya dijadikan sebagai intropeksi diri yang berkaitan dengan kemampuan, latihan, kekurangan dan potensi yang dimiliki oleh seseorang karyawan atau pegawai sehingga hasil penilaian tersebut dapat dijadikan sebagai penentuan jalur, tujuan, rencana dan pengembangan karier. Sedangkan bagi intitusi penilain terhadap kinerja pegawai memiliki manfaat dalam berbagai hal antara lain untuk mengidentifikasi kebutuhan dilaksanakanya kegiatan pendidikan dan pelatihan, rekruitmen, seleksi, program pengenalan, magang, penempatan dan promosi jabatan, Sondang (2016).

Pandangan dari para ahli misalnya Owens evaluasi atau penilaian diasumsikan memiliki tujuan untuk 1) evaluasi dan pertimbangan dalam menentukan jumlah gaji, 2) sebagai promosi dalam menentukan kenaikan pangkat, penurunan pangkat, pemberhentian, pemecatan pegawai, 3) pengembangan yang dijadikan sebagai pertimbangan dalam umpan balik, pengembnagan karier, perencanaan SDM, pengembangan organisasi, serta perbaikan kerja maupun hubungan komunikasi, Owens (1991). Dari pernyataan Owens maka Edgar H. Sechein menjelaskan lebih lanjut bahwa penilaian kinerja digunakan sebagai 1) umpan bailk dari karyawan ke organisasi, 2) mengukur kepuasan dan pertimbangan dalam menentukan program pengembangan, 3) sebagai landasan terhadap hasil seleksi yang telah dilakukan, 4) sebagai acuan dalam menentukan kompensasi, 5) sebagai pertimbangan memutuskan promosi jabatan atau mutasi, 6) sebagai pertimbangan dalam menyusun program disiplin kerja, Owens (1991).

Untuk merealisasikan penilaian kinerja maka dibutuhkanya prosedur secara resmi berdasarkan serangkaian kinerja yang telah ditetapkan. Sehingga dalam menjalankan penilaian kinerja terhadap pegawai, karyawan maupun pimpinan dilaksanakan secara teratur dan bersifat kontinuitas, orisinalitas, professional dan obyektif sehingga unsur- unsur yang dinilai merasa puas dan transparan, Sulhan (2012). Hal yang penting dalam Teknik penilaian kerja menurut Holley dan Junings ada komponen yang efektif untuk dilakukan yaitu: a) reliabel dan konsisten, b) valid yaitu meniali sesuai porsinya, c) berdsarkan standar yang mengacu pada kondisi dan standar yang terkendali, d) praktikalisasi dengan penilaian yang efektif dan efisien tidak boros, e) legalitas sesuai petunjuk yang sama, f) penilaian melalui penelitian, pengembangan, dan bimbingan pelatihan penilaian, Locneker (1985). Dalam pandangan lain berkaitan dnegan penilaian kinerja Rebert Bacal mengemukan bahwa penilaian merupakan sebuah proses yang mengevaluasi, mengukur kinerj individu maupun organisasi dengan melalui peringkatan atau sistem ranking, yang dilandasi sebuah tujuan, Pringle (1985).

Dari paparan para ahli tersebut maka dapat diambil kesimpulan bahwa dalam melaksanakan penilaian kinerja maka harus memperhatikan beberpa hal yaitu: 1) harus menggunakan alat penilaian yang valid dan reliabel, 2) penilaian harus mengguankan sistem yang efektif dan efisien tidak boros, 3) penilaian dilakukan berlandaskan tujuan yang telah ditetapkan. Ulasan lebih lanjut berkaitan standar kinerja merupakan rujukan yang dijadikan landasan mengukur kinerja oleh pimpinan kepada bawahan. Standar kinerja pada hakikatnya didasarkan pada dua informasi yang sangat penting yaitu keuntungan yang untuk pegawai dan keuntungan untuk organisasi selaku penilai. Selain itu standar kinerja merupakan informasi tentang identifikasi dan penjelasan tugas- tugas yang harus dilakukan oleh seluruh unsur organisasi baik pimpinan maupun karyawan.

Berkaitan dengan kinerja dosen maka sangat berfariasi dan banyak pengaruh terhadap masing- masing individu. Dalam tantangan di era 4.0 saat ini tantangan dosen semakin kompleks sehingga dibutuhkanya dosen yang memiliki prestasi tinggi. Beriringan dengan kondisi dan situasi yang sama para dosen membutuhkan yang namanya fad back dari kinerja yang telah dilakukan, sehingga penilaian dosen dilandaskan pada kinerja yang dihasilkanya. Dari hasil penilaian tersebut maka dapat dilihat sejauh mana kulitas dan kuantitas kinerja dosen dalam memenuhi standar kinerja yang telah tentukan oleh lembaga atau perguruan tinggi. Hasil penilaian kinerja dosen akan dijadikan refleksi yang penting bagi intitusi perguruan tinggi dalam mengukur maju tidaknya sebuah lembaga. Berdasarkan alasan tersebut maka sangat diperlukanya standar penilaian. Menurut Michell menjelaskan kinerja mencakup aspek antara lain kualitas kerja, ketepatan dan kecepatan dalam bekerja, inisiatif, kemampuan dan kominikasi. Dari seluruh aspek tersebut diperlukanya rumusan untuk pengkajian secara khusus dengan kemampuan dan komunikasi. Sehingga disini oleh peneliti dijadikan tolak ukur dalam penilaian kinerja dosen.

Standar kinerja merupakan tolak ukur untuk membandingkan antara apa yang telah dilakukan dengan apa yang diharapkan dalam jabatan dan pekerjaan yang diberikan kepada dosen. Standar kinerja dapat dijadikan standar pertanggung jawaban terhadap kinerja yang dilakukan. Secara spesifik Casio dalam Shulhan (2012) memaparkan kinerja menunjukan suatu capaian yang dihasilkan oleh seseorang dalam menjalankan tugasnya. Gambaran secara umum berkaitan dengan standar kinerja yang digunakan dalam penilaian PNS melipui beberapa komponen yaitu: 1) kesetiaan, 2) prestasi, 3) tanggung jawab, 4) ketaatan, 5) kejujuran, 6) kerja sama, 7) prakarsa, 8) kepemimpinan. Penjelasan lebih lanjut dipaparkan oleh Prabu Mangkunegara 
dalam Sulhan yaitu mencakup mutu pekerjaan, kejujuran, inisiatif, kehadiran, sikap, kerja sama, keandalan, pengetahuan, tantangan pekerjaan, tanggung jawab, dan pemanfaatan waktu kerja. seacra spesifik amgkunegara menjelaskan aspek- aspek standar kinerja yaitu: a) Aspek kuantitatif, terdiri dari proses kerja dan kondisi kerja, waktu yang digunakan, jumlah kesalahan, dan jumlah layanan dalam waktu bekerja; b) Aspek kualitatif, terdiketeri dari ketepatan kerja dan kualitas pekerjaan, tingkat kemampuan dalam bekerja, kemampuan menganalisis, dan kemampuan mengevaluasi.

Dari paparan di atas menunjukan hubungan yang erat antara kinerja dengan produktifitas, karena mengingat bahwa kinerja merupakan indikator dalam mencapai proses produktifitas setinggi mungkin dalam organisasi. Dalam konteks perguruan tinggi maka produktifitas dosen sangat dibutuhkan dalam penilaian kinerja. Produktifitas dosen meliputi bidang Pendidikan dan pengajaran, penelitian dan pengabdian. Dosen ditunut untuk produktif dalam menyiapkan materi perkuliahan, membuat modul, menyusun RPKPS, menyusun intrumen penilaian dan membuat diktat untuk mendukung kegiatan pengajaran di kampus. Di samping itu juga dosen harus produktif dalam kegiatan penelitian dan pengabdian masyarakat. Karena kegiatan tersebut akan dijadikan pokok penilaian dosen dalam hal publikasi, penyusunan artikel, HKI, paten, buku ajar, maupun sebagai laporan.

Adapun proses evaluasi terhadap kinerja dosen yang dilakukan rektor lebih cenderung bersifat kordinatif dengan para pejabat setruktural yang ada di UM Jember. Karena secara tersetruktur rektor dalam menjalankan perannya sebagai leader, consultan maupun supervisor dibantu oleh para Wakil Rektor. Begitu pula para wakil rektor di bantu oleh beberapa unit yang memiliki tugas dan fungsi yang berbeda- beda. Dari uraian di atas maka dapat dipahami bahwa gaya kepemimpinan rektor UM Jember dalam melaksanakan evaluasi terhadap kinerja dosen dilakukan secara birokratis yang bersifat kordinatif dengan para jajaran pimpinan setruktural dilingkungan UM Jember. Adapun cara mengevaluasi yakni dengan mendengarkan laporan dari para pimpinan yang memiliki tanggung jawab dan fungsi tertentu misalnya kinerja dosen. Para unit yang memiliki tugas untuk mengakomodir tentang kinerja caturdharma dosen yakni LPM, BAAK, LPPM, LPAIK dan LP3di bawah naungan Wakil Rektor I. Setelah mendengarkan uraian laporan dari para pimpinan maka rektor memberikan timbal balik berupa tanggapan penilaian yang bersifat kordinatif dan instruktif. Selain itu juga penilaian kinerja dosen dilakukan secara langsung dengan melibatkan biro kepegawaian di bawah naungan wakil rektor II mengintruksikan kepada para dosen untuk membuat SKP setiap tahunya. Dari SKP tersebut maka dapat diketahui sejauh mana kinerja dosen yang telah dilaksankan selama satu tahun yang terkait dengan catur dharma perguruan tinggi. Bila digambarkan maka evaluasi rektor terhadap kinerja dosen dapat dilihat di bawah ini:

\section{[Figure 5 abouthere.]}

Dari uraian di atas maka dapat dipahami bahwa dalam proses evaluasi kinerja terhadap dosen dilakukan secara kordinatif dengan para pimpinan yang memiliki tanggung jawab dan fungsi secara langsung maupun tidak langsung dengan menggunakan instrument penilaian kinerja.

\section{KESIMPULAN}

Gaya kepemimpinan rektor UM Jember dalam memberikan motivasi terhadap peningkatan kinerja dosen dilakukan secara birokratis. Adapun cara yang digunakan yaitu memotivasi langsung dengan Bahasa lisan pada agenda rapat, acara universitas, sosialisasi, kordinasi secara individu maupun general dengan ungkapan secara langsung (instruktif) maupun dengan makna tersirat (tidak bersifat instruktif). Berkaitan dengan upaya yang telah dilakukan rektor dalam meningkatkan kinerja dosen melalui beberapa program kerja yang telah diamanatkan kepada para pimpinan setruktural yang membawahi tugas tersebut dengan melibatkan pimpinan unit masing- masing di bawah naunganya. Secara praktis upaya yang telah dilakukan rektor terkait dengan kinerja dosen yang berhubungan dengan catur dharma perguruan tinggi yakni riset, pengajaran, pengabdian masyarakat dan Alislam kemuhammadiyahan. Sedangkan proses evaluasi kinerja terhadap dosen dilakukan secara kordinatif dengan para pimpinan yang memiliki tanggung jawab dan fungsi secara langsung maupun tidak langsung dengan menggunakan instrument penilaian kinerja.

\section{UCAPAN TERIMA KASIH}

Kami Ucapan terima kasih kepada Universitas Muhammadiyah Jember yang telah memberikan bantuan biaya penelitian tahun akademik 2020/ 2021. Selain itu terima kasih kepada seluruh unsur yang terlibat dalam penelitian ini yang tidak saya sebut satu persatu. Secara khusus kepada seluruh civitas akademika dan unsur yang membantu dalam proses penelitian di UM Jember dengan memberikan ijin, informasi maupun data guna untuk menyukseskan penelitian ini. Selain itu juga kami ucapkan terimaksih kepada Universitas Muhammadiyah Sidoarjo (UMSIDA) yang telah memberikan kesempatan dan ruang untuk publikasi dalam jurnal Halaqo SINTA 3 sebagai luaran penelitian ini. Disamping itu juga kami ucapkan terimaksih kepada Dr.Hj. Ilfi Nurdiana, S.Ag, M.Si dan Dr. Indah Yuliana, S.E, M.M dari UIN Maulana Malik Ibrahim Malang yang telah membimbing dan mengarahkan kegiatan penelitian, sekaligus mereview penulisan artikel ini sampai dengan publikasi. 


\section{REFERENCES}

Bahtiyar, N. (2013). Daya saing Perguruan Tinggi. Padang: Fakultas Ekonomi Universitas Andalas.

Bannet, N and Lesy, A. (2003). Rethinking Education Leadership. London: SAGE Publication.

Bogdan, R.C \& Biklen, S.K. (1992). Qualitative Reseach For Education An Introduction To Theory And Methods. Boston: Allyn \&Bacon.

Burhan B. (2017). Metodologi Penelitian Kualitatif, Aktualisasi Metodologis Kea Rah Ragam Varian Kontemporer, Depok: PR Rajagrafindo Persada.

Didin, K. (2015). Studi Prilaku Kepemimpinan Perguruan Tinggi Islam, Jurnal Administrasi Pendidikan, Vol, 22, No. 1 Hal. 83-97.

Dirawat, dkk. (2017). Pengantar Kepemimpinan Pendidikan Islam, Surabaya: Usaha Nasional

Edi, S.(2017)Manajemen Sumber Daya Manusia (Jakarta: Kencana Pernadamedia Group.

Emzir. (2016). Metodologi Penelitian Kualitatif, Analisis Data, Depok. PT Raja Grafindo Persada.

Fatma N, dkk. (2015). Faculty Member Perceptioans Of Department Head Leadership Effectiveness At State University Turkey. International Journal Of Leadership In Education. Vol. 18, Issue 4 Tahun 2015.

Gerry, D. (2000). Human Resource Management. Eight edition, New Jersey: Prentice Hall

Haris, A.K. Pengaruh Kompetensi, Kompensasi, Dan Budaya Organisasi Terhadap Kinerja Dosen Tetap Pada Perguruan Tinggi Swasta Di Kota Palu. Jurnal Universitas Muhamamdiyah Palu, Vol.4 No.3 Tahun 2012.

Hasan, L.(1991). Azaz-Azaz Pendidikan Islam, Jakarta: Pustaka Al-Husna.

Huda Dalam Tri, H.R. Kinerja Dosen Di Bidang Penelitian Dan Publikasi Ilmiah, Jurnal Akuntabilitas Maanjemen Pendidikan Vol, 6 No.2 Sepetember 2018.

I Wayan, G.S. (2019). Gaya Kepemimpinan Transformasional Dan Transaksional Serta Hubunganya Dengan Kinerja Karyawan, Jurnal Ilmiah Manajemen dan Bisnis, Vol.4, No, 2.

John, W C.(2015). Penelitian Kualitatif Dan Desain Riset, Yogyakarta: Pustaka Pelajar. Hlm 205-206.

Lijan, P.S. (2019). Manajemen Sumber Daya Manusia, Membangun Tim Yang Solid Untuk Meningkatkan Kinerja, Jakarta: Bumi Aksara.

M. Djunaidi G dan Fauzan, A. (2017). Metodologi Penelitian Kualitatif, Jogjakarta: Ar-Ruz Media.

Mudjia, R. (2018). Materi Mata Kuliah Metodologi Penelitian Kualitatif Program Doktor MPI UIN Maliki Malang.

Muwahid, S. (2012). Disertasi Gaya Kepemimpinan Madrasah Dalam Meningkatkan Kinerja Guru.

Norhani B, dkk (2020). The Role Of Transformation Leadership Promoting Sustainability Among Property Development Companies In Malaysia. International Journal Of Organization Leadership, vol. 9 tahun 2020.

Nurul, Q. Pengaruh Budaya Organisasi, Kepemimpinan, Dan Komitmen Organisasi Terhadap Kinerja Dosen Diperguruan Tinggi Swasta. Jurnal Universitas Muhamamdiyah Jember, Vol/1 No.3 2012.

Robert L. Malthis dan John H. Jacson, (2008) Human Resource Management. Terjemahan oleh Diana Angelica. (edisi ke 10) Jakarta: Salemba Empat.

Siti, M.H. (2018). Pengaruh Kepemimpinan, Lingkungan Kerja Dan Motivasi Kerja Terhadap Kinerja, Jurnal Ilmiah Magister Manajemen, Vol.1, No.1 Sepetember 2018, hal. 71-80.

Soewarto C.T, dkk. Pengaruh Gaya Kepemimpinan Terhadap Kinerja Dosen Dan
Kepusan Kerja Dan Motivasi Kerja Sebagai Mediator (Studi Pada Perguruan Tinggi Di Jayapura) Jurnal Aplikasi Manjemen vol. 10 No. 31 September 2012.

Soewarto, C.T.dkk. Pengaruh Gaya Kepemimpinan Terhadap Kinerja Dosen Dan Kepusan Kerja Dan Motivasi Kerja Sebagai Mediator (Studi Pada Perguruan Tinggi Di Jayapura) Jurnal Aplikasi Manjemen vol. 10 No. 31 September 2012.

Sugiono, (2017). Metode Penelitian Pendidikan, Pendekatan Kuantitatif, Kualitatif Dan R\&D, Bandung:CV Alfaberta.

Sugiyono, (2016). Metode Penelitian Manajemen, Bandung: Alfaberta.

Sugiyono, (2016). Metode Penelitian Manajemen, Bandung: Alfaberta.

Sumardi S, (1998). Metodologi Penelitian. Jakarta: Raja Grafindo.

Syahrizal, A. (2009) Manajmen Perguruan Tinggi, Jakarta: Kencana.

Uhar, S. (2015) Manajemen Perguruan Tinggi Strategi Menghadapi Perubahan (Bandung: PT. Refika Aditama.

Uhar, S. (2015). Manajemen Pendidikan Perguruan Tinggi, Bandung: Rafika Aditama.

Undang- Undang Republik Indonesia No. 12 Tahun 2012 Pasal 4 Tentang Pendidikan Tinggi.

Undang- Undang Republik Indonesia No. 12 Tahun 2012 Tentang Pendidikan Tinggi, Pasal 1 Ayat 2.

Wahyomijo. (2003) Kepemimpinan Kepala Sekolah, Tinjauan Teori dan Permasalahanya. Jakarta: PT. Raja Persada.

Yoyo, S. Dkk, (2018) Manajemen Sumber Daya Manusia, Kompensasi Tidak Langsung dan Lingkungan Kerja Fisik. Yogyakarta: CV. Andi Offset.

Yuditya, D.P. Dosen Indonesia Vs Swedia: Pengembangan Dosen Untuk Menghadapi Masyarakat Ekonomi Asia, Jurnal Eksekutif Volume 12. No. 2 Desember 2015. Hal. 382-383

Yukl dalam Husaini Usman. (2014). Manajemen Teori, Praktik dan Riset Pendidikan. Jakarta: Bumi Aksara.

Conflict of Interest Statement: The authors declare that the research was conducted in the absence of any commercial or financial relationships that could be construed as a potential conflict of interest.

Copyright (C) 2021 Saipul Wakit, Ilfi Nurdiana, Indah Yuliana . This is an openaccess article distributed under the terms of the Creative Commons Attribution License (CC BY). The use, distribution or reproduction in other forums is permitted, provided the origi-nal author(s) and the copyright owner(s) are credited and that the original publication in this journal is cited, in accordance with accepted academic practice. No use, distri- bution or reproduction is permitted which does not comply with these terms. 


\section{LIST OF TABLES}

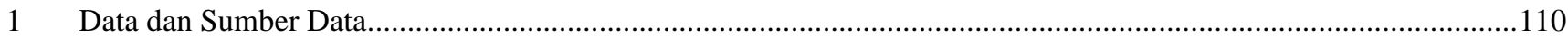

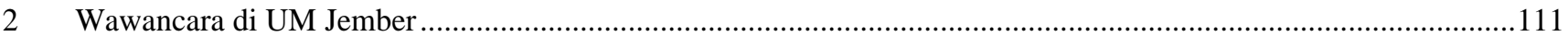

3 Daftar Dokumentasi 
TABLE 1/Data dan Sumber Data

SUMBER

Human

UM JEMBER

Bukan Orang Rektor, WAREK I, II, III, Kepala Biro Kepegawaian, Kepala LPPM, Kepala unit, dekan, kaprodi dan dosen

Dokumen dari LPPM, Dokumen data dosen, data kinerja dosen, P3DI, dan Renstra Maupun Renop Lembaga. 
TABLE 2 / Wawancara di UM

\section{No.}

1

2 engarahkan Dosen

3 enggerakan Dosen

valuasi Kinerja Dosen

\section{KONTEKS WAWANCARA}

Cara Rektor Dan Faktor- Faktor Yang Membangkitkan Semangat atau tindakan prilaku

Berkaitan dengan prilaku Rektor dalam, mengarahkan dan mengehentikan kinerja dosen

Berkaitan dengan prilaku Rektor Dalam menggerakan kinerja dosen dan mengehentikan

1) Tahap Persiapan merupakan kegiatan dimana para pimpinan dan karyawan memahami secara detail tentang arah tujuan Lembaga atau organisasi, dengan cara para pimpinan dan karyawan mengakaji dan menganalisis secara mandiri.

2) Tahap Pertemuan dilakukan oleh pimpinan maupun dosen kemudian merumuskan dan musyawarah pekerjaan yang akan dikerjakan pada waktu yang akan datang.

3) Tahap penutup merupakan tahap evaluasi atau penilaian yang dilakukan oleh pimpinan maupun dosen terhadap tugas- tugas atau pekerjaan yang belum selesai

\section{INFORMAN}

- Rektor, WR I, WR II, WR III, Kepala Unit, Staff BAAK, Dosen, Dekan, Kaprodi Senat Universitas

- Rektor, WR I, WR II, WR III, Kepala Unit , Staff BAAK, Dosen, Dekan, Kaprodi, Senat Universitas

- Rektor, WR I, WR II, WR III, Kepala Unit, Staff BAAK, Dosen, Dekan , Kaprodi, Senat Universitas

- Rektor

- WRI

- WR II

- WR III

- Dosen

- Dekan

- Kaprodi

- LPPM

- Cental HKI 
TABLE 3 / Daftar Dokumentasi

No.

Item Fokus Penelitian

$1 \quad$ Gaya kepemimpinan rektor dalam Memotivasi, Mengarahkan, Menggerakan dan evaluasi
Dokumen Yang Di Dapatkan

- Statuta PT

- Dokumen tugas Pokok rector dan wakil rector.

- Surat Keputusan Rektor, SK BPH

- Laporan BPH tentang evaluasi kinerja rector tahun 2019.

- Dokumentasi Humas UM Jember dan Dokumentasi kegiatan Rector Tahun 2019-2020

- Daftar Dosen, Laporan Kinerja Penelitian. PKM LPPM PT dan Laporan Kerja sentra HKI, Laporan WR I Kegiatan Pengajaran, Struktur Organisasi Kampus, Presensi dan Absen Proses Pengajaran yang Dilakukan Dosen

- Data Jumlah Mahaiswa, Data Jabatan Akademik Dosen

- Daftar Sertifikasi Dosen, Daftar Buku ajar Yang Dihasilkan dosen. 


\section{LIST OF FIGURE}

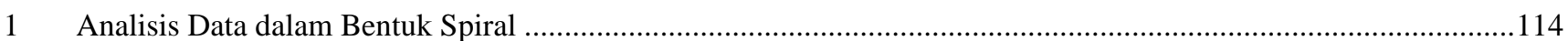

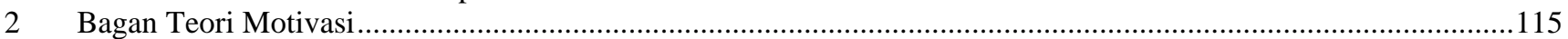

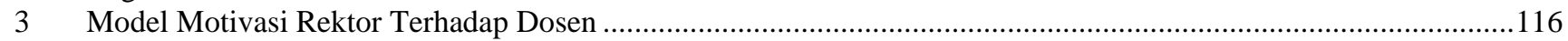

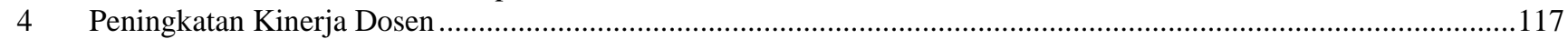

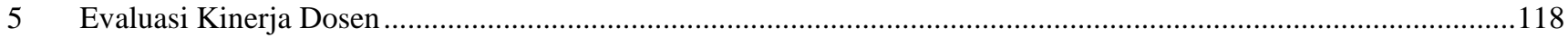




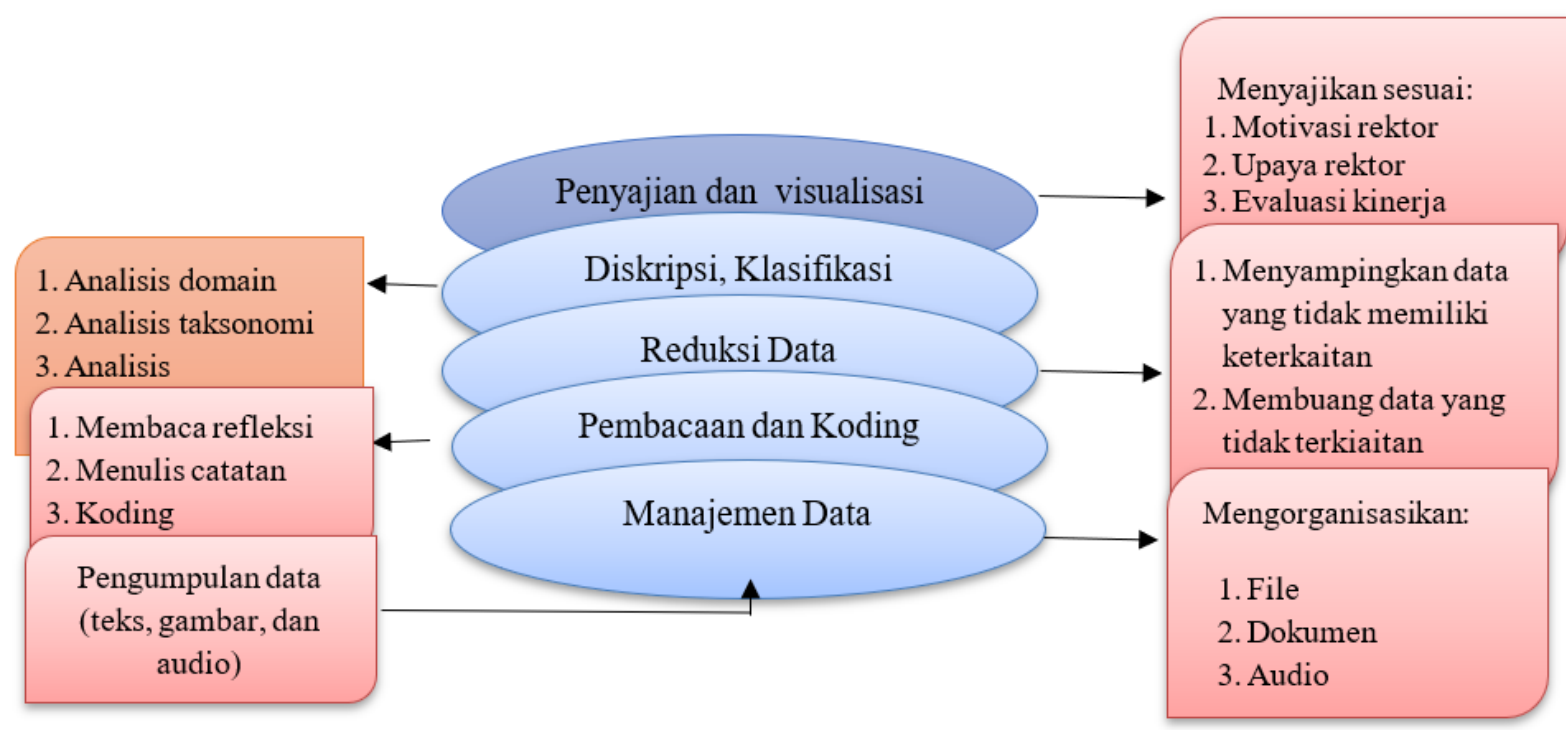

Sumber: John W.Creswell, Penelitian Kualitatif Dan Desain Riset. Yogyakarta: Pustaka Pelajar, 2014

FIGURE 1 / Analisis Data dalam Bentuk Spiral 


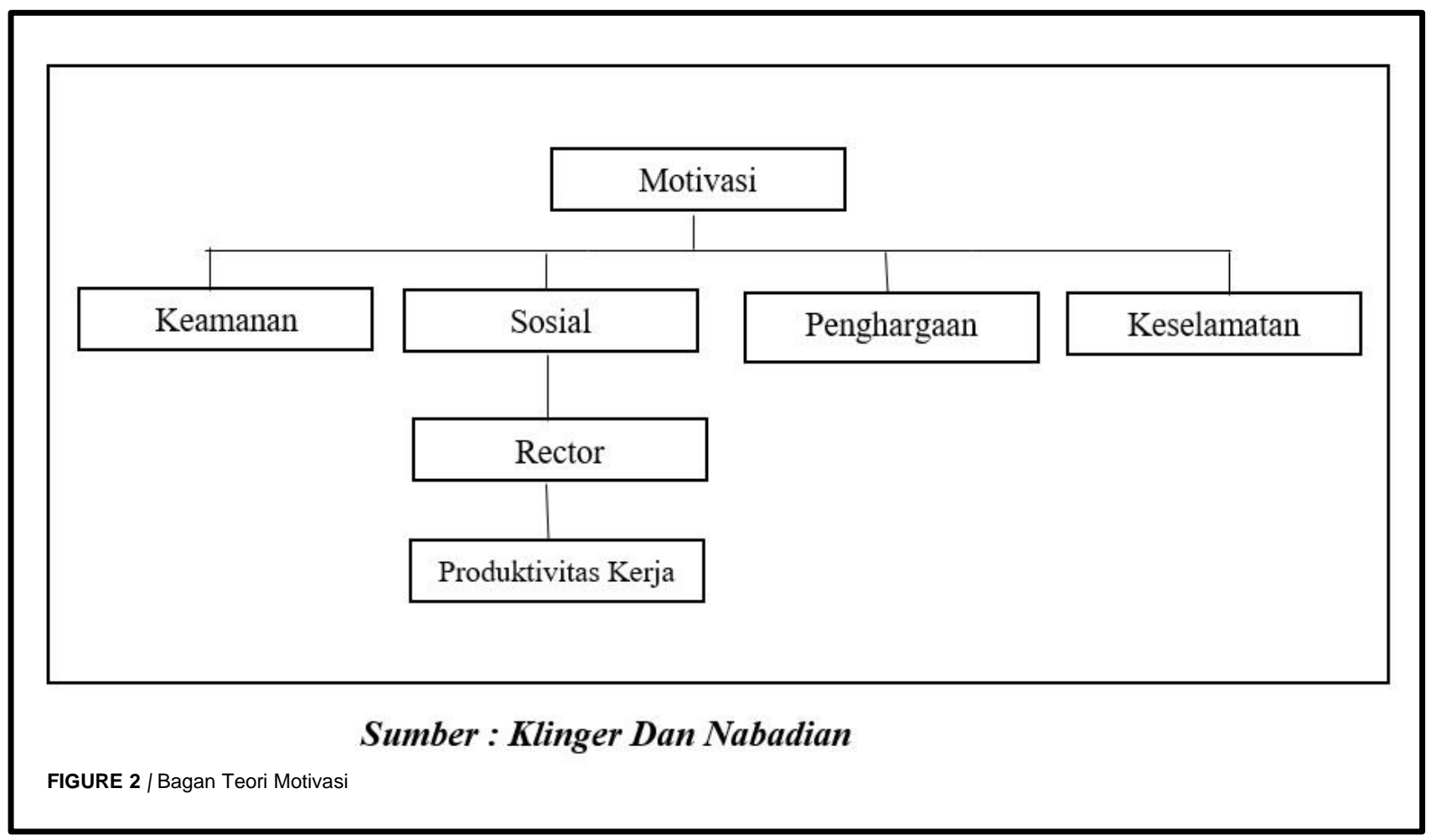




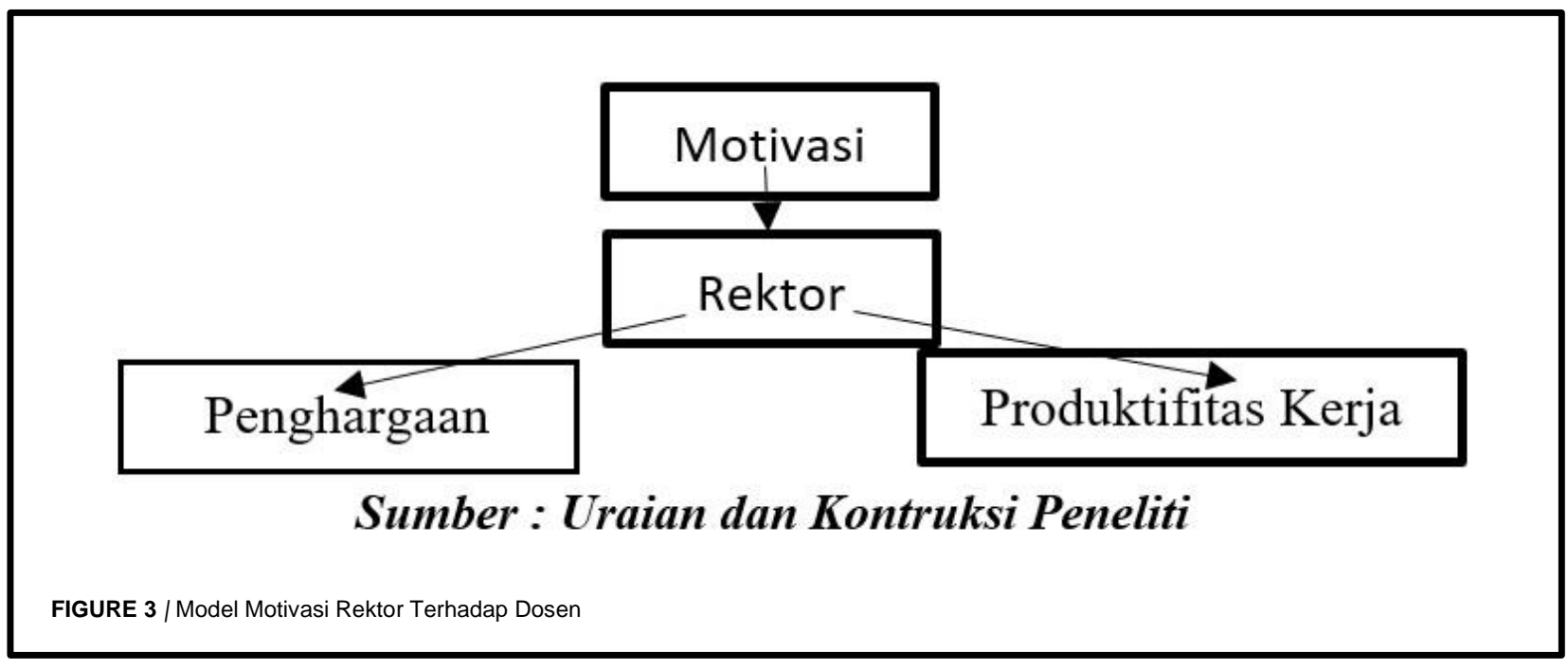




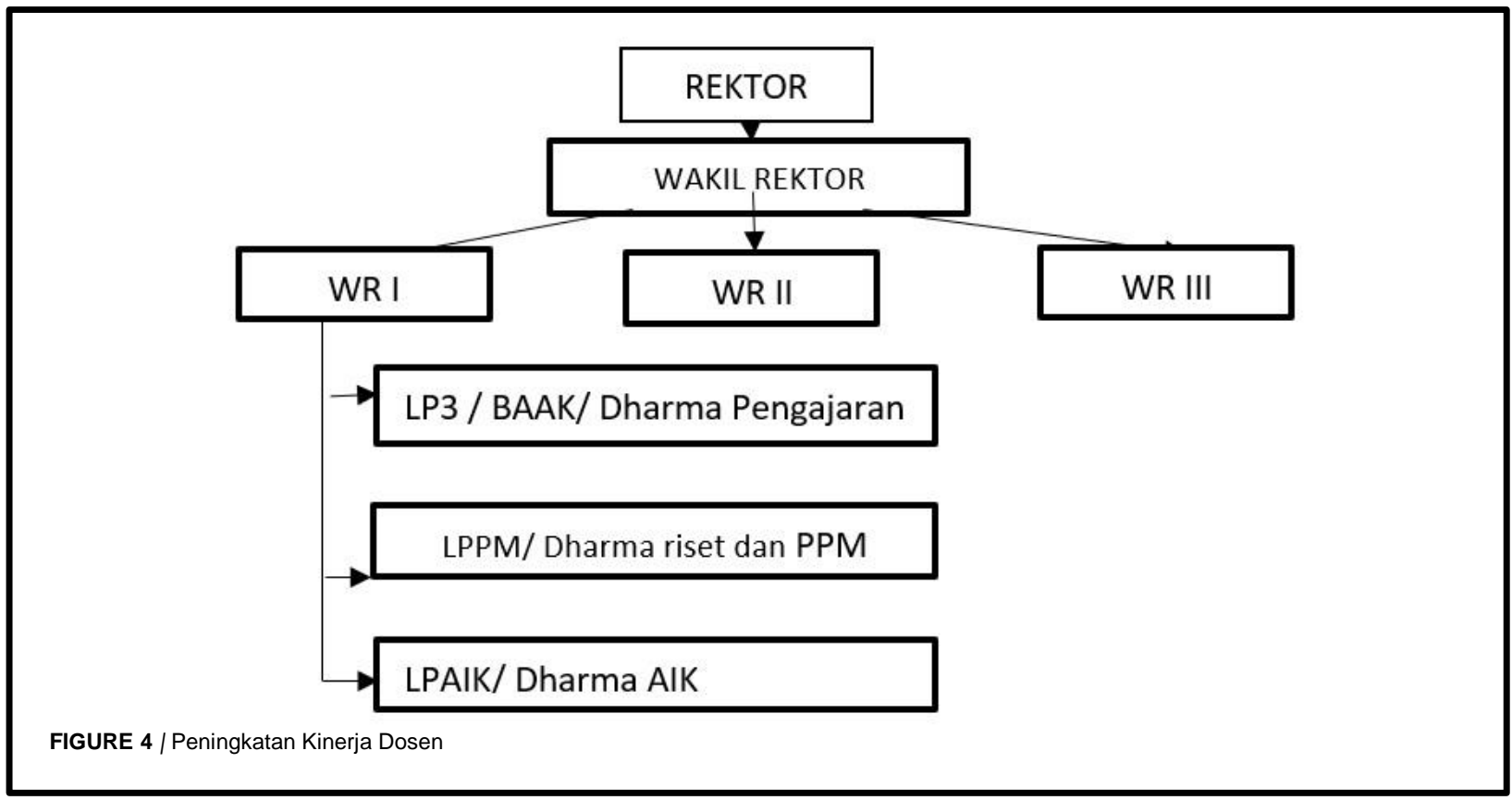




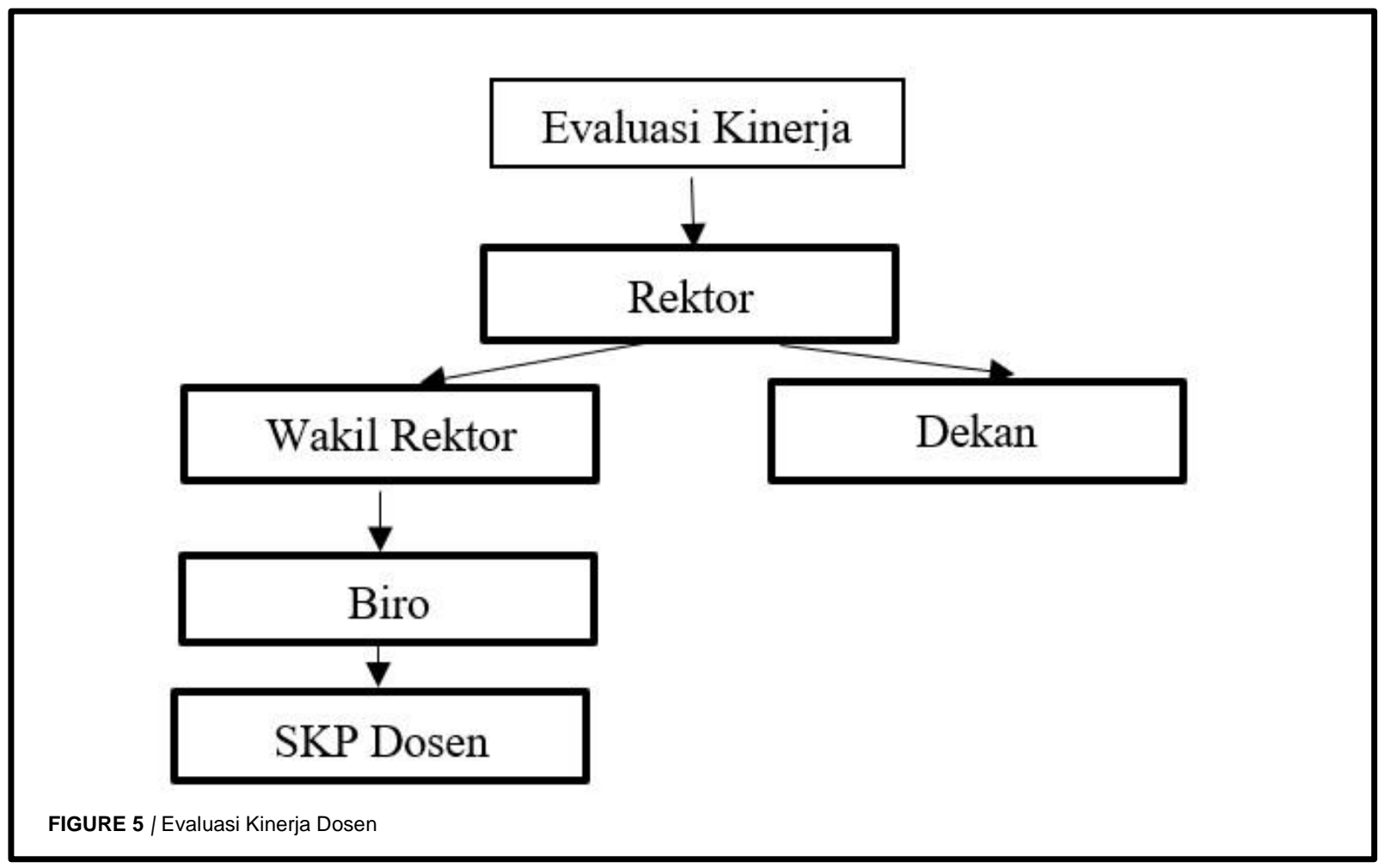

